\title{
Targeting Brazilian Market through Digital Branding Strategies: The Relevance of the Cultural Dimension
}

\author{
Lilian Maria de Souza Almeida \\ Academic Department, CETEC Educacional-ETEP Faculdades, Sao Jose dos Campos, Brazil \\ Email: lilian.almeida@etep.edu.br
}

Received 15 November 2014; revised 10 December 2014; accepted 25 December 2014

Copyright (C) 2015 by author and Scientific Research Publishing Inc.

This work is licensed under the Creative Commons Attribution International License (CC BY). http://creativecommons.org/licenses/by/4.0/

(c) (i) Open Access

\begin{abstract}
While Internet has been achieving its omnipresence worldwide and offering to companies the opportunity of trading in a "no-borders" market, global brands, and those aspiring to become global, face the challenge of dealing with significant cultural differences. Emergent economies account for one of the greatest opportunities for global brands interested in extending their business overseas through digital channels. Among these economies, Brazil has been receiving special focus lately as a promising consumer market. Working from a theoretical point of view through literature and simultaneously examining companies as potential paradigms, this study aims to provide suggestions for global brands interested in targeting the Brazilian market through effective cross-cultural digital branding strategies. The results are valuable insights about how to establish better communication with Brazilian consumers and also offer some guidance to help marketers to keep brands desired and admired in Brazil. It was mainly concluded that global brands should find out the right balance between a standardized and an adapted cultural approach in order to establish a trust-worthy proximity with Brazilian consumers on the digital environment.
\end{abstract}

\section{Keywords}

Cross-Cultural Marketing, Digital Marketing, Branding, Brazilian Market

\section{Introduction}

Among countless opportunities brought by Internet, the chance of doing business in a potential global market has been catching the attention of companies of different magnitude and natures. Consequently, interactions between different countries are growing exponentially. Not only has the Internet been the great catalyst of these 
cross-cultural business interactions but also the digital marketing has been challenged to be flexible enough to take into account the cultural peculiarities of different business scenarios.

Global digital marketing professionals must pay attention to the significant differences among markets that can affect the e-marketing strategy [1]. Not only may cultural misunderstandings be dangerous but also fatal [2]. It is believed that one of the greatest challenges for global digital marketing professionals will be related to developing new target markets among the emergent economies. Markets such as Brazil, Russia, India, China, and South Africa are especially attractive for digital marketing professionals because the fast growth of the middle class within those countries generates a substantial demand for products and services [1].

The proposal of this study is to identify appropriate cross-cultural digital branding strategies applicable at the Brazilian market. The economic growth that has been allowing millions of Brazilian consumers to start buying international products either by Internet or during traveling abroad brings opportunities with no precedence for global companies looking for developing new markets.

In order to achieve the established goal, not only a theoretical review was conducted but also it was highlighted some successful strategies of cross-cultural digital branding practiced by specific brands that have been achieving positive reactions among Brazilian consumers.

From the most loved brands by the Brazilian consumers [3], it was evaluated only the brands that do not have Brazil as their "country of origin" (COO), and among the set of the touch points considered in the process of digital branding [4] [5], the Web sites of these brands [6] [7] were taken as the main source of evidence for the proposal of this study.

In an effort to identify additional insightful strategies of cross-cultural digital branding, Nestlé was the company perceived as the benchmark of the group of the most loved brands at the Brazilian market [3]. Hence, this brand was chosen to be analyzed in a deeper level. The choice was based on the following criteria: a) the brand's original country is an example of low-context culture [7] [8] in contrast with the high-context Brazilian culture [9]; b) the brand's products can be considered non durable consumer goods and because of this it is expected a higher level of cultural adaptation on its digital strategy [6]; c) the brand is one of the world's most valuable brands [10] and it is one of the world's most reputable brands [11].

In the global Nestlé's Web site, it is possible to navigate through several versions from different nationalities of this same on-line channel. The Web sites from Switzerland and from Brazil were chosen as objects of comparison in order to identify the differences between the COO and the "foreign-target-market" approaches.

It is expected that this paper enables companies worldwide not only to see the Brazilian market as a great place of opportunities but also to elaborate on how to make their brands gain Brazilian consumers attention and admiration in the challenging digital environment.

\section{Brazilian Contemporary Facts}

\subsection{Digital Environment}

The process of digital inclusion within Brazil has been accelerating, growing from a rate of $20.9 \%$ of Internet users above ten years old in 2005 to $46.5 \%$ of the same rate in 2011 [12]. The current number of Brazilian connected by Internet either in their homes or in their workplaces is more than 105 million [13]. Simultaneously to the growth of the Internet access in the country, Brazilian consumers have also been surrendering to the convenience of the on-line shopping experience. The sector of e-commerce registered $\mathrm{R} \$ 28.8$ billion in sales throughout the year of 2013, which corresponds to $28 \%$ nominal growth compared to 2012. The result exceeded the expectations since initially it was predicted that the sector would have a $25 \%$ growth [14].

Brazilian shoppers have been showing their interest in global brands since it became easier both the Internet access and the accomplishment of the dream of traveling abroad. Brazil was one of the six key markets investigated in [15]. The most important Brazilian facts reported through this study are subsequently summarized: a) Brazilian cross-border shoppers accounted for 5.3 million, spending $\mathrm{R} \$ 2.6$ billion in 2013; b) It is expected up to 9.4 million on-line cross-border shoppers, spending $\mathrm{R} \$ 16.8$ billion a year by 2018; c) Brazilian shop are mainly from United States (79\%), China (48\%), Hong Kong (17\%), United Kingdom (17\%) and Canada (14\%).

Brazilian market is also one of the "unusual territories" where the luxury brands have been growing in levels above 20\%. This trend, which is not only observed in Brazil but also in countries like India and China, has been boosted by affluent customers and social status seekers. Because consumers from developing countries exhibit similar interest in branded products as wealthy countries, marketers of luxury products should not overlook po- 
tential segments in the developing world [16]. This observation may be seen as an opportunity for global luxury brands interested in developing new markets, taking advantage of the Internet as a channel for establishing relationship with prospect customers from emerging economies.

All the mentioned data suggest that Brazil is a potential market for global brands from different natures and countries of origin. Hence, companies seeking to succeed at the Brazilian market are invited to know deeply the cultural aspects of this country.

\subsection{Cultural Highlights}

The Brazilian culture is often associated, if not restricted, to the image of carnival, samba, soccer and Amazon. While those associations are not deceptive, several additional cultural aspects should be known and evaluated before starting doing business at the Brazilian market. Brazilian people have been mistakenly considered Hispanic. Formed by European immigrants, African slaves and descendants, and natives, the country doesn't have a homogeneous culture. Brazilian culture is also marked by a strong influence of the Catholic Church which was present since the beginning of the Portuguese colonization. Brazilian people can be considered extroverted. Regarding the family environment they may be described as supportive, protective, and responsible for the maintenance of relationship links [17].

An interesting analysis of the Brazilian culture from an outside perspective was presented in [9], through which the main points of the Brazilian culture that may be relevant for those interested in doing business across the country are summarized. In the Table 1, it is summed up the most relevant data collected from this initiative of describing Brazilian culture.

\section{Cross-Cultural Digital Marketing}

Although the notion of a global culture is inherent to the spirit of the modern times [18], it is noticeable that some local cultural roots seem to be perennial in a number of societies. Therefore, these specific cultural roots should never be ignored by global brands trying to target new consumers overseas. Culture is the main determinant of the behavior and the desires of consumers [19]. Among hundreds of available definitions, culture is generally defined as a sum of ways of life that includes behaviors, beliefs, values, languages and living practices shared by a society. The function of culture is to establish modes of conduct, standards of performance and ways of dealing with interpersonal and environmental relations [2]. Culture encompasses both abstract and tangible elements. Among the abstract elements it can be included values, attitudes, ideas, personality types, religion and political beliefs. Tangible elements account for cultural artifacts such as books, tools, buildings, products and even brands [20].

One of the most challenging but also critical factors for succeeding in doing business in a foreign country is to understand the differences in cultural perceptions and values, the differences in needs within a society. Since marketing is based upon satisfying the customers' needs and needs are very much culturally based, a successful cross-marketing strategy only can be defined after a deep and careful understanding of the culture mores of the country to which a company is trying to market [2]. The same idea can be applied to digital marketing strategies, since this new model can be generally understood as the "use of the information technology for the marketing

Table 1. Brazilian cultural highlights [9].

\begin{tabular}{|c|c|c|}
\hline \multirow{2}{*}{$\begin{array}{l}\text { Cultural } \\
\text { Dimension }\end{array}$} & \multicolumn{2}{|c|}{ Brazilian Characteristics } \\
\hline & Communication Style & Business Aspects \\
\hline & $\begin{array}{l}\text { Brazilian communication style is very expressive and animated: } \\
\text { they like to say things giving examples and details. The writing style } \\
\text { shares many characteristics with the oral communication and } \\
\text { commas are largely adopted. Brazilian culture is more high-context } \\
\text { than American and North European and this feature affects both } \\
\text { verbal and non-verbal communication aspects. The use of an } \\
\text { indirect style of communication is more frequent than in other } \\
\text { cultures; it is imperative to be aware of the possible underlying } \\
\text { meanings in the communication exchanges. Close physical contact } \\
\text { is the norm; the distance between individuals is usually short and } \\
\text { touching during a conversation is normal. }\end{array}$ & $\begin{array}{l}\text { Negotiations cannot be rushed in this country; business } \\
\text { is done with friends, and friendships take a long time to } \\
\text { build. Brazilians idea of time is more flexible than it is in } \\
\text { some cultures; it is common for meetings to start } 5 \text { - } 20 \\
\text { minutes late. }\end{array}$ \\
\hline
\end{tabular}


activities” [1].

The core dilemma among companies interested in trading overseas is to decide between selling global brands throughout the foreign markets and making the needed modifications according to local preferences. This dilemma is also called the debate between standardizing operations and adapting to local environments and it is still ongoing [21].

When analyzing foreign markets in order to explore new opportunities, digital marketing professionals should balance two different approaches: market differences and market similarities. Market differences encompass the set of characteristics involving language, culture, consumer behavior, and so on. Market similarities are the common points between two markets. According to the market similarity approach, marketing professionals should firstly select foreign markets that have similar characteristics related to their domestic markets. An American company, for instance, should focus the Canadian, Australian and British markets in the beginning of an internationalization strategy, before focusing in Japan, France or Germany [1]. Cultural differences will have to be considered in some point of the marketing plan, even if there are several similarities between the COO and the targeted new market [20].

Some insightful marketing strategies are suggested to companies interested in performing better in overseas markets and in minimizing cross-cultural mistakes: a) develop cultural empathy, being sensitive to do's and taboos of the target foreign market; b) respect another's culture and differences, trying to recognize, understand and accept them; c) choose culturally neutral strategies when appropriate; d) never automatically transfer concepts from one culture to another; e) avoid self-reference criteria, assuming that what is appreciated by one is also appreciated by others [2].

The debate between the standardized and the adapted strategies, which has resulted in a "cultural-free" and a "cultural-bound" approach, is not a modern conflict among marketing professionals [20] [21], but it is even more relevant in the current context of the "Internet Era”. Web sites of global companies that are primarily based on Web activities and e-commerce, such as Amazon for instance, tend to be strongly standardized and dominated by rational content appeals, by layouts presenting significant amount of text, small pictures only, high interactivity, structured content, intensive navigation support and other singular characteristics. Global brands of durable products, such as Sony, present their Web sites with a certain level of standardization, focusing on universal brand-related colors, graphics and uniform frames of content. A higher degree of cultural adaptation can be observed in the Web sites of global brands of non durable products like Coca-Cola [6].

While Internet has assumed to cross culture barriers, people in different countries use it in different ways [6] and therefore local strategies and adaptations cannot be ignored. Since the Internet consumption varies from one country to another depending on different culture natures, the impact of the Internet on different nations will also vary significant.

The different Internet usage rates are especially linked with the peculiarities of high and low-context cultures. This widely known and explored approach considers that people from high-context cultures usually have extensive information networks among family, friends, colleagues and clients and are involved in close personal relationships. Japanese, Arabs and Mediterranean peoples and their interactions are examples of high-context cultures. In the high-context communities, people keep themselves informed about everything having to do with people who are important in their lives. On the other hand, people from low-context cultures tend to compartmentalize their personal relationships, their work and other aspects of their lives. Consequently, they need detailed background information in their interactions with others. Americans, Germans, Swiss and Scandinavians can be included in the low-context culture's group [8].

Reflections about the approaches of high and low-context cultures on the digital marketing, and specifically concerning the design of Web sites are presented in [7]. Based on the premise that the customization of Web sites cannot be merely a translation of texts and that the overall communication strategy should also be appropriated to the audience, the author conducted a cross-cultural analysis of Web sites from Japan, China, and Korea (high-context cultures) and from Germany, Denmark, Sweden, Norway, Finland, and the United States (low-context cultures). Among the main findings of this study, it can be underlined that differences in communication styles between high-context and low-context cultures clearly occur on the Web. Additional conclusions reached by the author are following listed: a) animations of people are more frequent in high-context culture's Web sites, revealing values attributed to collectivistic societies; b) Web sites of high-context cultures are more likely to use images to convey information, in contrast to low-context Web sites that are more likely to use texts in some situations; c) the co-presence of products and people are more present in high-context culture's Web 
sites, while in low-context Web sites products and consumers are more likely to be shown separately; d) values expressed through images tend to be consistent with those prevailing in the culture of the countries in both high and low-context cultures which can be respectively associated with collectivism and individualism.

\section{Cross-Cultural Digital Branding}

Having a strong and reliable brand on the Web is very important, especially in an unfamiliar purchasing situation like the Internet [5]. After the Internet, the branding process has become even more important because the multiplied number of options and the impersonal nature of the relationships between customers and companies at the on-line environment have led consumers to look for trust-worthy brands [22].

In addition to being a "name, term, design, symbol, or any other feature that identifies one seller's good or service as distinct from those of other sellers" [23], brands are recognized as a key-element of the relationship between the company and its consumers [24]. A brand is a mixture of attributes, tangible and intangible, symbolized in a trademark, which, if managed properly, creates value and influence [25].

Contemporary brands need to be multidimensional, strategic and flexible. The multidimensional attribute is associated with the brand's ability of expressing themselves in ways that work for them, no matter if having a personality, using organizational values as points of differentiation or delivering functional benefits. The brand conception cannot be constrained by a "fill in the box" model. A brand also should be strategic, reflecting not only the existing offering, but also the role that the brand will play in future offerings and in supporting other brands. Finally, the brand must be flexible in the sense that the goal should be having strong brands in every product category and in every country it is offered [26].

Brands have to be carefully and strategically established and managed through an effective branding process. Branding is defined as the process of giving products the power of a brand and according to these authors this process is directly related to create differences. It can be applied to any category in which customers have a variety of options, including goods, services, retailing and so on [19].

The new digital environment brought several challenges to the branding process. Digital branding is not only about logos and visual identity, celebrity endorsements and sports team sponsorship. The digital branding process is really about the sum of all the consumer on-line experiences. Although these experiences may be influenced by logos and sponsorships, the digital branding should be understood as something beyond visual identity [5].

One of the first steps of the branding process on the Internet is the creation of an efficient Web site. Web sites are the first point of interaction between the brand and the consumers and also one of the prime tools to engage them [4]. In fact, the Web sites are only one of the touch points that must be managed in the process of digital branding [5]. Essentially, digital branding is about creating and managing the personality of an organization, service or product, considering all experiences that an individual has with a brand, including his or her interactions with the company through important touch points such as social media and on-line reviews. Branding has changed because the digital media and the communication between brands and consumers now occurs through a two-way channel. Conversation is no longer one way and it represents not only a challenge but also an opportunity for brands worldwide. Digital media gave the consumers the chance to meet the true personality of a brand. In an effort to manage the experiences that the consumers are going to have with brands, the process of digital branding does not exclude the traditional initiatives like the tone of voice used by the call center employees, but provide several additional on-line experiences that must be tied together by the classical marketing tools. In [5] it is suggested a digital toolkit includes social media, search engine optimization, mobile marketing, on-line advertising, e-mail marketing and customer relationship management (CRM).

In order to honor the promise that a brand represents, companies operating in the on-line context should adopt strategies that generate trust among customers because the company-client distance can cause stress and concern related to safety and privacy. The use of cultural elements such as music, sports and entertainment when correctly associated with brands enable them to touch customers emotionally [1].

Occasionally, some brands become strong symbols of its original country. Brands like McDonald's and CocaCola may be considered real icons of the American culture [7]. Brands like Mercedes-Benz for instance tend to use the typical communication style of its COO, even if a positive effect is difficult to be successfully achieved because it works only in cases where the images of the product and its $\mathrm{COO}$ are positively related in the target countries. While the national representation through the design of a Web site can generate trust when utilized in the right targets, culture-specific adaptations are more appropriate or even mandatory in some cases in order to 
reduce the "not-invented-here" feelings [6]. COO effects are not uniform for consumers with different cultural orientations. While consumers from collectivistic cultures have a stronger influence of COO image on their consumption behavior regarding utilitarian products, individualistic consumers have a strong influence of COO image for hedonic products. Consequently, marketers should highlight the hedonic elements of products in order to attract consumers with individualistic orientations and they should emphasize the utilitarian aspects when the trying to get the attention of collectivistic consumers [27].

There are advantages and disadvantages that should be considered when adopting either standardized or adapted strategies across borders. Considerations involving costs, brand image, advertising and others should be carefully analyzed. If the target countries require specific adaptations in the marketing program, companies can fail if do not apply the needed changes in their strategies. On the other hand, when a unified brand image is possible to be applied, huge savings may be reached if the standardization strategy is adopted [20].

\section{Brazilian Consumers and Their Most Loved Brands}

Some of the Brazilian culture features may be associated with the consumer behavior towards brands within the country. In a recent study called "Loved Brands" [3], it was revealed that every brand trying to develop a stronger relationship with the Brazilian consumer must consider two main dimensions: proximity and affection, both sustained by high quality products and services.

The study also revealed that, among the top ten most loved brands, global brands were significantly present. This observation suggests that these international brands have been successfully communicating and creating relationship with the Brazilian consumers.

The ranking of the ten most loved brands [3] and their respective nationalities can be checked in Table 2 .

\section{Discussion}

An interesting observation regarding the most loved brands in the Brazilian market is the significant presence of aspirational luxury brands such as Louis Vuitton, Prada, Rolex, Gucci and Mont Blanc, confirming some of the conclusions presented in [16]. However, if it is considered that the collectivism is one of the prevailing values of the Brazilian culture [17], the admiration for luxury brands among Brazilian people does not reconciles with the idea advocated in [27] that the positive influence of $\mathrm{COO}$ image regarding hedonic products tends to be weaker in collectivistic cultures than the same kind influence associated with utilitarian products. While these brands can only be acquired by a wealthier minority of the country, it seems that Brazilian consumers love them because they are icons of an ambitioned life: the first world lifestyle. It is also noticeable that these luxury brands usually adopt the standardized approach for their Web sites, which partially weakens one of the observations

Table 2. Brazilian most loved brands [3].

\begin{tabular}{ccc}
\hline & Brazilian Most Loved Brands & \\
\hline Rank & Brand & Country of Origin \\
\hline 1 & O Boticário & Brazil \\
2 & Natura & France \\
3 & Louis Vuitton & Brazil \\
4 & Nestlé & Italy \\
5 & Havaianas & England/Italy \\
6 & Prada & Germany \\
7 & Rolex/Gucci & United States \\
\hline
\end{tabular}


found in [6] concerning the difficulty of achieving a positive COO effect. A very low level of adaptation can be found in the Brazilian Web site of Louis Vuitton [28], where it is announced an exclusive new model of bag inspired in the city of Rio de Janeiro. Other on-line communication strategies utilized by the aspirational brands are restricted to either the translation of texts or the indication of local stores in Brazil. These characteristics suggest that the standardized approach adopted by luxury brands in the digital context may be linked to the intention of making their Web sites be recognized as an official on-line channel, especially in a country where the falsification of luxury brands is very common. As a matter of fact, it was observed in [16] that the increasing consumer interest in luxury brands among emerging economies has also led to the proliferation of fake and counterfeit products.

Samsung and Tommy Hilfiger utilize a certain level of adaptation in their Brazilian Web sites. Promotions culturally designed can be found at the Samsung's home page [29], including images of people wearing yellow shirts which evoke Brazilian sports' teams. At the Tommy Hilfiger's Web site [30], a proximity strategy can be observed. Not only is it announced that the brand's products are being sold through the e-commerce channel, but also it is offered free shipping to Brazil in the case of acquisitions above five hundred "reais" (R\$500.00).

Nestlé's Web sites display a higher level of adaptation and this characteristic regarding to on-line pages of non durable products was also noticed in [6].

Based on the first impact generated when accessing the home pages of both the Swiss and the Brazilian Nestlé's Web sites [31] [32], it is easy to notice that the company prefers using the adaptation instead of a completely standardized style. While in the Swiss home page [31] the images of scientific and rational appeals are explored in half of the pictures that are alternately exposed, in the Brazilian Nestlé's home page [32] the alternate images mainly communicate about promotions and added services such as typical recipes culturally conceived with Brazilian ingredients (Figure 1). Through one of these images, the on-line consumer is invited to learn about typical Brazilian drinks from different States of the country. Digital magazines are offered with suggestions of recipes of Brazilian food that can be served to friends and family.

Although Switzerland is deemed a country of low-context culture's prevalence [8] and therefore it is a nation that has the individualism as one of its values [7], elements of collectivism involving the family context can also be found in some images at the Swiss Nestlé's Web site [31]. The same typical family's scene is presented at the Brazilian Nestlé's Web site [32], as it can be verified in the Figure 1, however the ethnic type of the family displayed differs from the Swiss Web site. Both Web sites present people together in the home context with and without products of Nestlé.

Animations are also used on the Web sites of both nationalities, leading to the conclusion that this kind of resource is not necessarily related to the low or high-context culture's criteria, as observed in [7]. The standard blue color of Nestlé is present in both Swiss and Brazilian Web sites as well as the traditional logo with birds in a nest and the slogan "Good food. Good Life". In the Brazilian home page, however, an additional slogan is used: the slogan "Nestlé: Faz Bem" in Portuguese language means something similar to "Nestlé makes you feel good" [32].

Signs of proximity and affection are widely perceived in the language style used in the Brazilian Nestlé's Web site [32]. This perception suggests that the brand establishes an appropriate communication with Brazilian consumers and it is probably related to the time of experience that the company has acquired after years operating in Brazil.

Founded in Switzerland in 1866, Nestlé offers its goods in Brazil since 1921. The company’s mission statement in Brazil is described as "offering products recognized for its leadership in goods of quality and nutritive value, contributing for a healthier and pleasant feeding and generating business opportunities for the company and shared value with the Brazilian society” [32].

\section{Conclusions}

Brazilian consumers have an undeniable openness to international products and this fact may be influenced by the country's culture of hosting foreign people in a very friendly way. This reality was confirmed through the "Loved Brands" study through which it was revealed that, from the top ten most loved brands at the Brazilian market, only three are national brands. Additionally, the global most loved brands comes from different countries, which suggests that the Brazilian consumers enjoy the variety and do not have negative attitudes towards specific countries when it is a matter of choosing brands. 

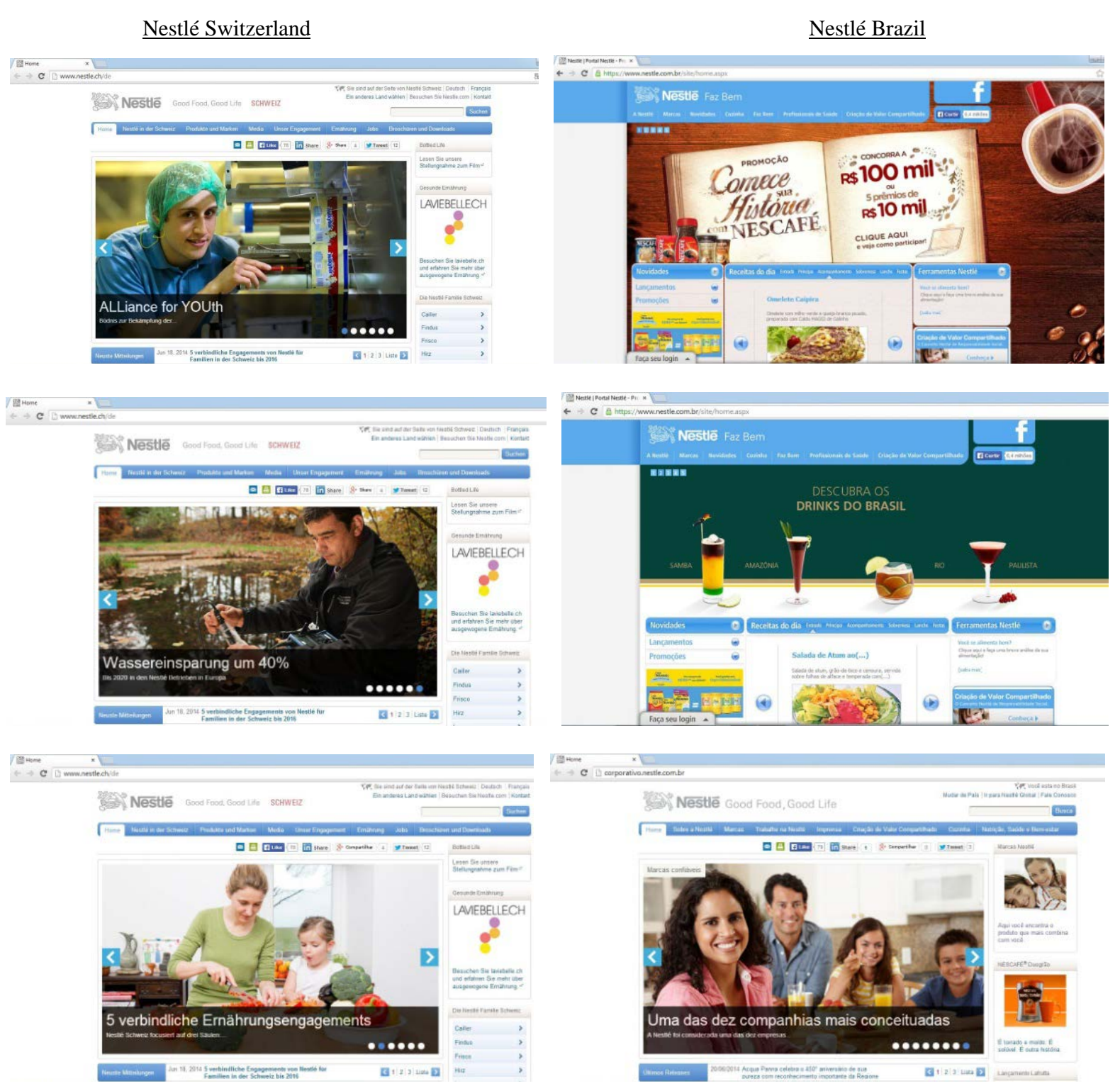

Figure 1. Comparison of the Nestlé’s Swiss and Brazilian Web sites [31] [32].

Companies interested in make their brands stand out in the Brazilian on-line environment must find a balance between a standardized and an adapted digital approach. While the genuine origin of the brand can be reinforced by the use of standard colors, logos and slogans, the adoption of a culturally adapted communication style can touch the Brazilian consumer emotionally through images, texts, sounds, animations and other digital resources. Therefore the challenge is to know how many culturally adapted icons should be evoked in a reliable, genuine and standardized Web site.

Proximity and affection are values that can be widely explored, since Brazilian people experience the collectivism much more than the individualism as a general lifestyle. Not only should brands understand this kind of relationship among Brazilians but also they are challenged to convey the same sense of union when trying to make their brands become loved by consumers within Brazil. Besides, it is most likely that reaching this positive feeling from Brazilians will demand high investment of time and effort, because Brazilian people are used to developing trust-worthy relationships only in the long term.

The digital environment is a great touch point to start building the brand awareness and a closer relationship with the Brazilian consumer since the Internet access and the engagement in on-line activities is growing fast in Brazil.

If the brand is linked to initiatives of environmental and social responsibility, it should be communicated 
through its digital channels as a way to improve the company's reputation. This strategy is likely to generate positive reactions among Brazilian consumers that have become more aware of the sustainability concept.

It is important to consider the limitations of this study as opportunities for future research. In addition to the companies' Web sites that were taken as the only touch point of the consumer experience, strategies like the brand presence in different social media, digital advertising, email marketing and other customer relationship initiatives should be evaluated through deeper investigations. Moreover, while this study is just about the "business-to-consumer" relations and does not encompass the "business-to-business" interactions, further research can be developed beginning from this paper. Ultimately, although the only ambition of this paper was to be a start point for deeper investigation, it is successful in providing a different perspective of the Brazilian market for companies interested in exploring this emerging economy through digital means.

\section{References}

[1] Strauss, J. and Frost, R. (2012) E-Marketing. Pearson Prentice Hall, São Paulo.

[2] Herbig, P.A. (2013) Handbook of Cross-Cultural Marketing. Routledge, New York.

[3] Consumidor Moderno (2014) A Evolução do Consumidor. http://www.consumidormoderno.com.br/impressas/CM190.pdf

[4] Limba, T., Kiskis, M. and Jurkute, V. (2014) Online Brand Experience Creation Process Model: Theoretical Insights. International Journal of Advanced Computer Science and Information Technology, 3, 100-118.

[5] Rowles, D. (2014) Digital Branding: A Complete Step-by-Step Guide to Strategy, Tactics and Measurement. Kogan Page, Philadelphia.

[6] Hermeking, M. (2006) Culture and Internet Consumption: Contributions from Cross-Cultural Marketing and Advertising Research. Journal of Computer-Mediated Communication, 11, 192-216. http://dx.doi.org/10.1111/j.1083-6101.2006.tb00310.x

[7] Würtz, E. (2006) Intercultural Communication on Web Sites: A Cross-Cultural Analysis of Web Sites from High-Context Cultures and Low-Context Cultures. Journal of Computer-Mediated Communication, 11, 274-299. http://dx.doi.org/10.1111/j.1083-6101.2006.tb00313.x

[8] Hall, E.T. and Hall, M.R. (1990) Understanding Cultural Differences: Germans, French and Americans. Intercultural Press, Boston.

[9] Moran, R.T., Abramson, N.R. and Moran, S.V. (2014) Managing Cultural Differences. Routledge, New York.

[10] Forbes (2014) The World’s Most Valuable Brands. http://www.forbes.com/powerful-brands/list/

[11] Reputation Institute (2014) Meeting the Demands of Consumers. http://www.reputationinstitute.com/thought-leadership/global-reptrak-100

[12] Instituto Brasileiro de Geografia e Estatística (2011) Pesquisa Nacional por Amostra de Domicílios: Acesso à Internet e Posse de Telefone Móvel Celular para Uso Pessoal. ftp://ftp.ibge.gov.br/Acesso_a_internet_e_posse_celular/2011/PNAD_Inter_2011.pdf

[13] Nielsen (2014) Número de usuários ativos passa de 60 milhões pela primeira vez. http://www.nielsen.com/br/pt/nielsen-pressroom/2014/numero-de-usuarios-ativos-passa-de-60-milhoes-pela-primeira-v ez.html

[14] E-BIT (2014) Relatório Webshoppers 2014: 29a edição. http://www.ebit.com.br/webshoppers

[15] PayPal (2013) Modern Spice Routes: The Cultural Impact and Economic Opportunity of Cross-Border Shopping. https://www.paypal-media.com/assets/pdf/fact_sheet/PayPal_ModernSpiceRoutes_Report_Final.pdf

[16] Souiden, N., M’Saad, B. and Pons, F. (2011) A Cross-Cultural Analysis of Consumers' Conspicuous Consumption of Branded Fashion Accessories. Journal of International Consumer Marketing, 23, 329-343. http://dx.doi.org/10.1080/08961530.2011.602951

[17] Fleith, D.S. (2011) Creativity in the Brazilian Culture. Online Readings in Psychology and Culture, 4, 3. http://scholarworks.gvsu.edu/orpc/vol4/iss3/3/

[18] Kraidy, M.M. (2005) Hybridity, or the Cultural Logic of Globalization. Temple University Press, Philadelphia.

[19] Kotler, P. and Keller, K.L. (2006) Administração de Marketing. Pearson Prentice Hall, São Paulo.

[20] Blackwell, R.D., Miniard, P.W. and Engel, J.F. (2005) Comportamento do Consumidor. Pioneira Thomson Learning, São Paulo.

[21] De Mooij, M.K. (2013) Global Marketing and Advertising: Understanding Cultural Paradoxes. Sage Publications, Thousand Oaks. 
[22] Wind, J. and Mahajan, V. (2001) Digital Marketing: Digital Strategies from the World’s Leading Experts. John Wiley \& Sons, Inc., New York.

[23] American Marketing Association (2014) Dictionary. https://www.ama.org/resources/Pages/Dictionary.aspx?dLetter=B\&dLetter=B

[24] Kotler, P. and Armstrong, G. (2007) Princípios de Marketing. Pearson Prentice Hall, São Paulo.

[25] Brand Channel (2014) Brand Careers_Glossary. http://www.brandchannel.com/education_glossary.asp

[26] Aaker, D. (2014) The Five Biggest Ideas of the Branding Era. https://www.ama.org/publications/MarketingNews/Pages/five-biggest-ideas-branding-era.aspx

[27] Sharma, P. (2011) Demystifying Cultural Differences in Country-of-Origin Effects: Exploring the Moderating Roles of Product Type, Consumption Context, and Involvement. Journal of International Consumer Marketing, 23, 344-364. http://dx.doi.org/10.1080/08961530.2011.602952

[28] Louis Vuitton (2014) Lançamento da Edição Limitada Cabas Rio. http://br.louisvuitton.com/front/\#/por_BR/News/articles/LANCAMENTO-DA-EDICAO-LIMITADA-CABAS-RIO

[29] Samsung (2014) Promoções. http://www.samsung.com/br/promotions/

[30] Tommy Hilfiger (2014) Tommy Hilfiger. http://br.tommy.com/

[31] Nestlé Switzerland (2014) Nestlé: Good Food. Good Life. http://www.nestle.ch/de

[32] Nestlé Brasil (2014) Nestlé: Faz Bem. https://www.nestle.com.br/site/home.aspx 
Scientific Research Publishing (SCIRP) is one of the largest Open Access journal publishers. It is currently publishing more than 200 open access, online, peer-reviewed journals covering a wide range of academic disciplines. SCIRP serves the worldwide academic communities and contributes to the progress and application of science with its publication.

Other selected journals from SCIRP are listed as below. Submit your manuscript to us via either submit@scirp.org or Online Submission Portal.
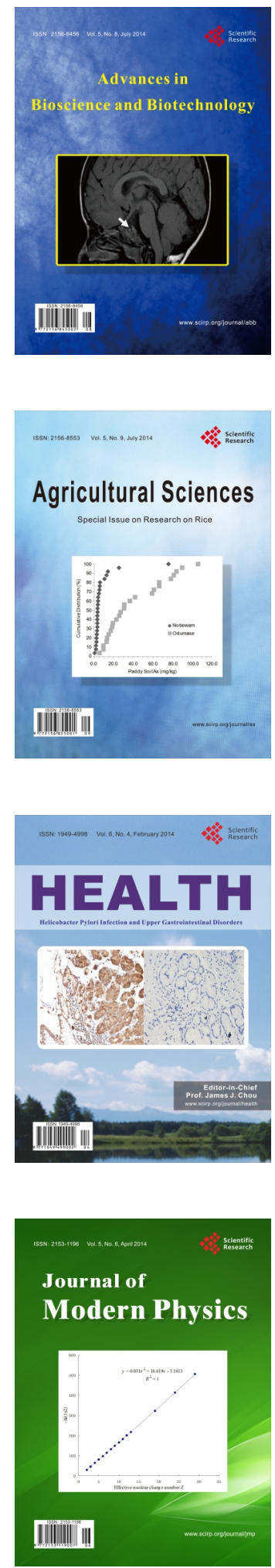
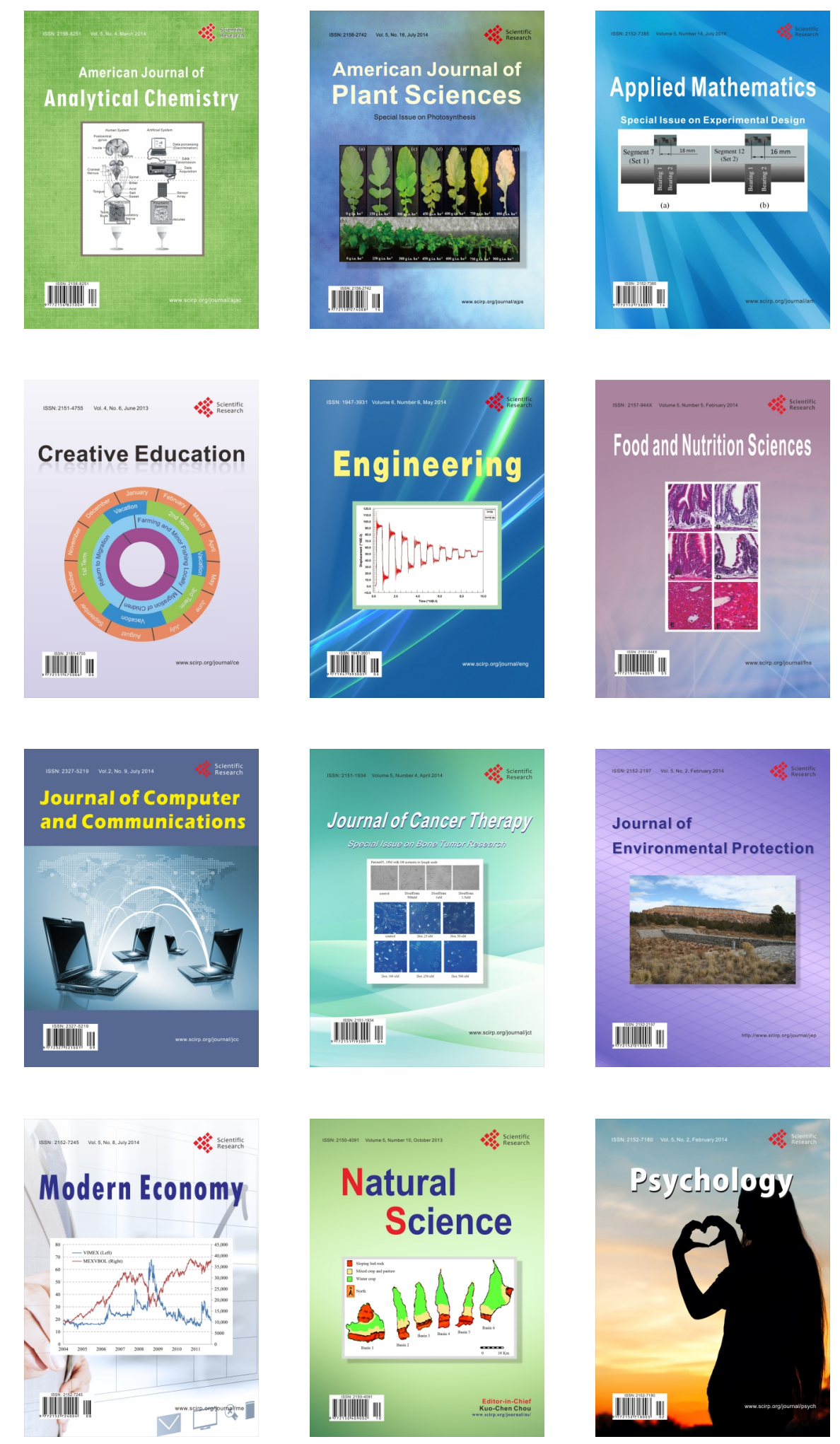